\title{
Progressing the rights to light debate Part I: A review of current practice
}

\begin{abstract}
Introduces a series of articles which respond to Pitts' (2000) call for a debate into current rights to light practice. Summarises relevant areas of law as well as current measurement and valuation practices in this area. Describes the Waldram methodology, the grumble point, the fifty-fifty rule and the concept of Equivalent First Zone Loss. Shows how these concepts are used to determine the amount of damages payable where a right to light has been infringed. Calls for others to contribute to the debate proposed by Pitts.
\end{abstract}

\section{Keywords}

Rights to Light, Easement, Waldram, Grumble Point, Fifty-Fifty Rule, Equivalent First Zone, Parasitic Damages.

\section{Introduction}

In a previous issue of this journal Pitts (2000) called for a debate on the continued relevance of current surveying practice in rights to light cases. Specifically, he invited discussion on the use of the so-called 'fifty-fifty' rule and on whether the use of the traditional 'grumble point' could still be justified. Four years later that call remains unanswered. The lack of response may, at least in part, reflect the small pool of expertise in the field and the difficulties encountered by most practitioners in gaining access to the relevant professional knowledge in this area.

This is the first in a series of articles which have been written in response to Pitts' earlier contribution. The current article reviews the nature of current rights to light practice and cites key historical sources to enable interested readers to acquaint themselves with its underlying principles. The hope is that this may facilitate the debate and encourage others to comment on the validity of the current methodology as Pitts had hoped. 
Two subsequent articles will perhaps go further than Pitts had anticipated. He questioned whether technological advances and increasing expectations about levels of illumination have made current practices obsolete. These articles will instead question the theoretical basis of the practices themselves. They will trace the historical development of the current methodology and will argue, contrary to all expectations, that it is actually unsupported by any reliable empirical or scientific evidence.

\section{Advising on the right to light}

In this article, let us first consider the nature of rights to light cases in which surveyors are asked to advise. These typically arise in city centre redevelopment projects where pressures to maximise floor area result in the construction of higher and wider buildings than those being replaced. In many situations this will have a detrimental effect on the availability of daylight for neighbouring buildings and the question of an interference with their rights to light will arise.

There is no general entitlement to receive compensation for a loss of daylight. This will only arise in situations where a legal right to light actually exists and where this has also been infringed. In these circumstances an injured party will be entitled to an award of damages and, in exceptional circumstances, to an injunction to prevent the infringement from taking place.

Whilst there is no natural right to light ${ }^{1}$, the law does recognise it as a type of easement (Gaunt \& Morgan 1997, p. 291). To be effective, therefore, a right to light must have been brought into existence by one of the mechanisms recognised for the creation of easements generally (Gaunt \& Morgan 1997, pp. 99 - 239).

In most cases this will be through the doctrine of prescription. Thus, rights to light (termed 'ancient lights') will exist in respect of windows which have continually enjoyed light for a period of 20 years without interruption ${ }^{2}$. Although this situation will not exist universally, many buildings erected more than 20 years ago can be expected to have such a right, providing there has been little neighbouring development during the past 20 years. 
The existence of a right to light can therefore be ascertained from the history of an affected building and of its immediate environment. The question of whether the right has been infringed, and therefore whether damages are payable, is not so easily answered.

The legal principles are well established. The owner of a right to light does not have a proprietary right to all the light flowing through his window but only to a particular quantity of light ${ }^{3}$. It is therefore possible for him to suffer a significant obstruction of his light without his right to light being infringed and therefore, at least in theory, without him suffering any loss of value.

To establish an infringement of his right to light, and therefore his entitlement to damages, the owner must also show that the quantity of light remaining after erection of the obstruction is less than that recognised by law. The quantity so recognised has been variously described as "sufficient light according to the ordinary notions of mankind" ${ }^{4}$ and "sufficient light, according to ordinary notions, for the comfortable or beneficial use of the building in question" ${ }^{5}$.

The difficulty, for the surveyor, is not one of understanding the legal principles but of applying them in practice. The concept of sufficiency, judged according to ordinary notions of mankind, makes perfect sense in theory. But, when asked to advise on the impact of a proposed development on a neighbouring building, how does the surveyor apply such abstract concepts to the realities of a specific situation on site?

\section{Percy J Waldram}

No one has done more to answer the above question than Percy J Waldram, a chartered surveyor and lighting engineer, who pioneered the study of daylight during the first half of the twentieth century. The methodology which he developed during this period is largely that which is used today by surveyors in measuring and valuing the loss of daylight.

He noted the huge variations in sky luminance due to changes in weather conditions and also the vast capacity of the human eye to cope with these over very short periods. Rather than measuring interior daylight illumination in absolute terms at a particular 
moment in time, he therefore proposed that it should be expressed as a ratio of the total illumination simultaneously available outside from the dome of an unobstructed sky (Waldram 1909, p.135).

Today, we refer to this ratio as the 'sky factor' (British Standards Institution 1992, p. 2). Whatever the luminance of the sky at a particular time, this ratio remains constant. It is therefore synonymous with the percentage of sky which is visible from a given point inside a building. Thus, the sky factor on the unobstructed roof of a building is $100 \%$ whilst that at the back of a room where no sky is visible is $0 \%$. The maximum possible sky factor from a single window (50\%) is theoretically available at the cill of an upstairs window looking out over an unobstructed landscape. In the majority of locations within a room the sky factor will be substantially less than this theoretical maximum.

Based on his own investigations Waldram (1923, p. 96) suggested that the threshold of adequate daylight "for ordinary purposes, comparable with clerical work" was represented by a sky factor of $0.2 \%$. He maintained that this was the level at which "average reasonable persons would consistently grumble" and it has therefore become known as the grumble point.

Waldram used these findings in his work as a rights to light surveyor. Specifically, he argued that, as the demonstrable threshold of adequate daylight, the $0.2 \%$ grumble point must, by definition, also represent the legal threshold of "sufficient light according to the ordinary notions of mankind". The grumble point therefore provided the practical benchmark which surveyors required, to enable them to determine whether a right to light had been infringed in a particular situation.

In the absence of any credible challenge, this argument was accepted, firstly by Waldram's professional opponents (Commission Internationale de L'Eclairage 1932, pp. 212 - 213) and eventually, in 1922, by the courts in Semon \& Co v Bradford Corporation $^{6}$. The methodology was subsequently endorsed by Mr Justice Upjohn in the case of Cory $v$ City of London Real Property Co $\mathrm{Ltd}^{7}$ and is now universally adopted by practising rights to light surveyors. 


\section{The surveyor's task}

\section{The $\mathbf{0 . 2 \%}$ sky factor contour}

The first stage of the surveyor's task is to plot a number of points on a plan of the affected room, all representing the position of the $0.2 \%$ sky factor at a plane (the 'working plane') $850 \mathrm{~mm}$ above floor level. Once sufficient points have been plotted they can be joined together to form a single contour. This is often referred to as the 'grumble line'.

\section{Locating the $0.2 \%$ contour}

The points on the grumble line are obtained by combining information from construction drawings and site surveys with a graphical representation of a theoretical overcast sky of uniform luminance distribution.

A detailed consideration of these methods is beyond the scope of this article but those wishing to research them further will find them fully described in Walsh (1961, chapters 5 \& 11). Traditionally they involved the construction of Waldram diagrams (see Figure 1) on which the visible sky from each point under consideration was shown graphically on a two-dimensional representation of the overcast sky. As several diagrams might have to be produced to identify a single point on the grumble line this was an extremely labour intensive process.

\section{[Take in Figure 1]}

For this reason it is now more usual for grumble lines to be plotted with the aid of specialist software which records percentage sky visibility from various points within a CAD-generated virtual environment. This is not yet commercially available but many practitioners have commissioned bespoke programmes which typically operate within the industry-standard AutoCAD software (Lawson 1996) (Defoe 1997).

\section{Preparation of daylight plan}

The whole exercise will actually be carried out twice to enable grumble lines to be plotted in respect of the situations both before and after erection of the offending obstruction. The resulting plan, showing the two grumble lines, is often referred to as a 'daylight plan' (see Figure 2). The daylight plan can then be used to determine 
whether a right to light has been infringed and if so, to provide a basis for the valuation of the consequent loss of light.

[Take in Figure 2]

\section{Determining whether infringement has occurred}

The position of the second grumble line (representing the $0.2 \%$ sky factor after erection of the obstruction) is used to determine whether an infringement has occurred.

The courts originally took the view that infringement occurred if any part of a room was reduced to this threshold level of illumination ${ }^{8}$. A few years later Waldram (1928, p. 489) was suggesting that up to $50 \%$ of a room could be reduced to this level without infringement and this rule (the 'fifty-fifty' rule) has now become accepted practice.

Thus, to determine whether damages are payable, the surveyor will simply measure the floor area lying inside the second grumble line (see Figure 3). If this area exceeds $50 \%$ of the total floor area then the building owner generally has no entitlement to redress for the obstruction to his light. However, if the room is left with less than $50 \%$ of its floor area at the threshold level of illumination then an actionable injury (the tort of nuisance) is generally taken to have occurred ${ }^{9}$. This can then be quantified by the surveyor.

\section{[Take in Figure 3]}

\section{Assessment of damages}

\section{Measurement of floor area}

The surveyor must determine the diminution in the value of the property which has been caused by the infringement of the right to light. This is calculated on a room by room basis according to the amount of floor area which has been reduced below the threshold level of illumination. The floor area loss for each room is therefore represented by the area lying between the two grumble lines on the daylight plan (see Figure 4). 


\section{[Take in Figure 4]}

However, prior to valuation, the area so affected is weighted according to the seriousness of the loss of light which has been suffered. In this regard losses are treated as being of increasing significance as the percentage of the room receiving adequate light decreases. Hence the loss is apportioned between four possible zones, each carrying a different weighting, depending on the area in which it occurs. These zones, and their standard weightings, are shown in Table I.

\section{[Take in Table I]}

To take a simple example, assume that a room has a floor area of $100 \mathrm{~m}^{2}$. Assume that $95 \mathrm{~m}^{2}$ of the floor area receives adequate light ( $0.2 \%$ sky factor or more) and that this is then reduced to $39 \mathrm{~m}^{2}$ by the erection of a neighbouring building. The area of loss is therefore $56 \mathrm{~m}^{2}$.

As $39 \mathrm{~m}^{2}$ of the room continues to have adequate light, the front $25 \%$ of the room (25 $\mathrm{m}^{2}$ ) is unaffected and there is therefore no front zone loss. However, $11 \mathrm{~m}^{2}$ of the loss falls in front of the $50 \%$ threshold and is therefore classed as first zone loss. The remaining $45 \mathrm{~m}^{2}$ of loss is then apportioned between second zone $\left(25 \mathrm{~m}^{2}\right)$ and makeweight $\left(20 \mathrm{~m}^{2}\right)$ loss.

The resulting weighted floor area loss, to be used as a basis for valuation, is referred to as the equivalent first zone loss (or 'EFZ' loss). If the standard weightings are applied to the losses described in this example, they will be found to produce an EFZ loss of $28.5 \mathrm{~m}^{2}$. In practice, for valuation purposes in the UK, this would normally be expressed in imperial measurements, namely, $307 \mathrm{ft}^{2}$.

\section{Valuation of freehold interest in possession}

Where the injured party is a freeholder in possession the valuation of loss is relatively straightforward. The EFZ loss is simply multiplied by the current market rental figure and then capitalised to produce a lump sum. 
However, the relevant market rental figure is only that proportion of the total market rent which reflects the availability of daylight. This will vary depending on the type and location of the property under consideration. As a general rule the availability of daylight is assumed to contribute a greater proportion of the total value as the level of specification decreases and as the distance from prime locations increases.

Daylight proportions for various locations and property types have been described by Anstey (1988, pp. 71 - 73) in a number of graphs and these are said to reflect a broad consensus amongst practitioners. By way of illustration, the proportions for 'high tech' office rents in London are said to range from approximately $16 \%$ of rental value for the lowest rents down to approximately 6\% for the highest. According to Anstey's figures, and on the basis of a presumed spread of annual rents from $£ 32 / \mathrm{ft}^{2}$ to $£ 85 / \mathrm{ft}^{2}$, the daylight rental proportion for this category of property would typically be in the region of $£ 5 / \mathrm{ft}^{2}$ per annum (see Figure 5).

\section{[Take in Figure 5]}

If this annual rent $\left(£ 5 / \mathrm{ft}^{2}\right)$ is multiplied by the EFZ loss from our earlier example (307 $\mathrm{ft}^{2}$ ) the annual loss of rent, for the single room under consideration, will be seen to be $£ 1,535$. This figure must then be capitalised by multiplying it by an appropriate year's purchase (YP) in perpetuity. Assuming a yield of 6\%, and therefore a YP of 16.6667, the total compensation payable to the freeholder in possession is therefore $£ 25,583$. This is referred to as the 'book value'.

\section{Valuation of leasehold interests}

Where leasehold or sub-leasehold interests are also present the owner of the freehold interest will still receive the entire book value in situations where the lease reserves all rights to light to the head landlord.

Where the rights are not so reserved, although the total damages payable are still calculated on the basis of the book value, these must then be apportioned between the various owners. Apportionment is made according to the length of the unexpired term or, where there is an intervening rent review, according to the length of time remaining until the next review. 
The calculation can be illustrated by reference to our earlier example. Let us assume that the property is subject to a headlease having a 10 year unexpired term (without review) and to a sub-lease with 5 years remaining until the next rent review. The apportionment can then be made using the appropriate YP for each interest as shown in Table II.

\section{[Take in Table II]}

Thus, whilst the total damages payable for the loss remains unchanged at $£ 25,583$, the freeholder only receives $£ 14,275.31$ (55.8\%) of this with the remainder going to the owner of the leasehold interests in the proportions shown in the table.

\section{Adjustments to book value}

In practice, a number of adjustments may be made to the above calculations. The first of these concerns the calculation of EFZ for rooms where the right to light has been infringed. The standard weightings described above were first articulated by Anstey (1981, pp. 10 - 11) and for many years represented the norm. However it is now increasingly common for surveyors to promote any makeweight loss to second zone loss with consequent increases in the overall EFZ loss. In our example this would result in an increase in the EFZ loss from $28.5 \mathrm{~m}^{2}\left(307 \mathrm{ft}^{2}\right)$ to $33.5 \mathrm{~m}^{2}\left(360 \mathrm{ft}^{2}\right)$.

The second adjustment relates to rooms which experience some loss of light but where the room itself suffers no legal infringement as more than 50\% remains adequately lit. It should be noted that damages are based on the diminution in the value of a property as a whole and not simply on that suffered by individual rooms. Hence, where a right has been infringed in respect of one room, damages will also be available in respect of other rooms in the same building where these experience a loss which would not by itself be actionable.

In the context of rights to light this principle was first recognised in Re London Tilbury and Southend Railway Company ${ }^{10}$ and since then has become known as the doctrine of 'parasitic damages' (Street 1906, pp. 461 et seq). Surveyors will therefore calculate EFZ losses for all affected rooms in a building providing that at least one of 
them has also sustained an actionable injury. These 'parasitic' losses, by definition, only take place in the second zone and makeweight areas of the rooms. For the purpose of EFZ calculations, any second zone losses are demoted to makeweight and all parasitic injuries are therefore valued at $25 \%$ of their actual floor area.

The final adjustment to the book value will only be required in situations where the infringement is sufficiently serious to merit the award of an injunction. Although it is notoriously difficult to predict these situations with any confidence, they typically arise where large losses are suffered or where a much smaller loss leaves an already poorly lit room in an even worse situation ${ }^{11}$.

In situations where an injured party is entitled to an injunction the court may nevertheless exercise its discretion to grant equitable damages instead. ${ }^{12}$ Unlike common law damages, which compensate for existing losses, these damages reflect the fact that the injured party is to be deprived of his rights in perpetuity (Jolowicz 1975). They are therefore assessed on a more generous basis than the principles so far considered.

In Carr-Saunders v Dick McNeil Associates Limited ${ }^{13}$ Millet J. held that this should take account of the injured party's bargaining position as well as the amount of profit the developer stood to make by infringing his rights. On this basis the judge awarded damages of $£ 8,000$ in circumstances where the book value was $£ 3,000$. Since this case, although surveyors recognise that each injunctable situation will be decided on its own particular facts, a figure of two and a half to three times the book value is often taken as a starting point for damages in these circumstances (Anstey 1995), (Ellis 1989, p.37).

\section{Conclusions}

This article has described the current practice in rights to light disputes. It has explained the legal basis for the right to light and the consequences which flow from its infringement. In circumstances where an infringement occurs it has described the methods used by surveyors to determine the appropriate level of damages to be awarded to the injured party. 
It has been shown that all parts of this complex and multi-disciplinary area of practice rest on the methodology which was proposed by Waldram in the early part of the twentieth century and which has been generally accepted by the courts since 1922 . This is characterised by the production of daylight plans which show the movement of a 'grumble line' on a room plan due to the obstruction of daylight by a neighbouring development. The status of the 'grumble line' and the significance of the related 'fifty-fifty' rule are therefore central to all decisions made by surveyors in this area of practice.

It is hoped that this account, and some of the historic sources cited within it, will provide the basis for others to comment on the validity of current practice from the perspective of their own professional disciplines. Contributions from those with a professional or academic involvement in valuation or daylight design would, of course, be especially pertinent to the current debate. As described in the introduction, the next article in this series will describe the origins of the Waldram methodology and question whether current practice is justified in being so dependent upon it. 


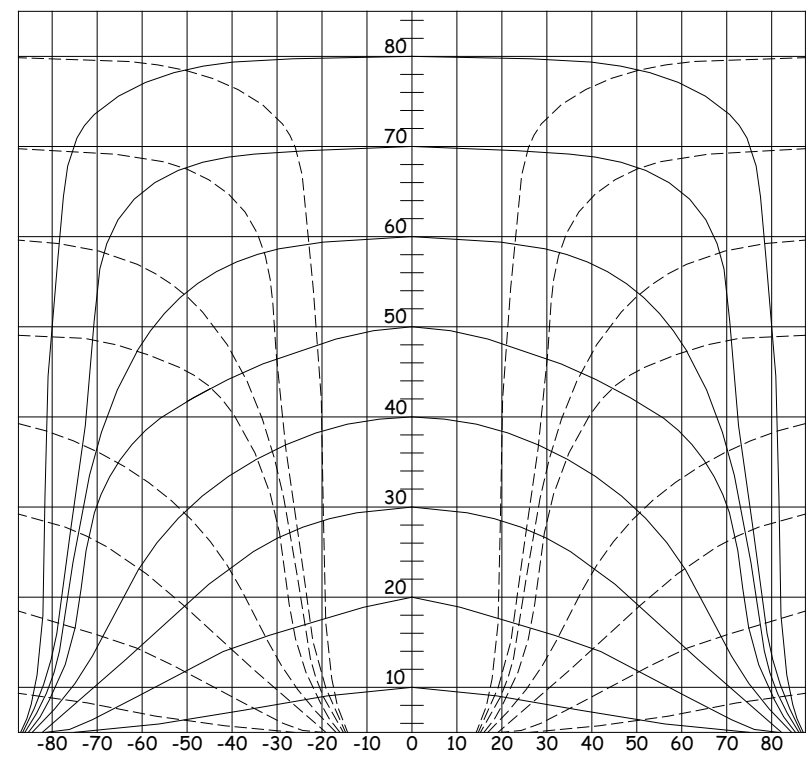

Figure 1: Waldram Diagram

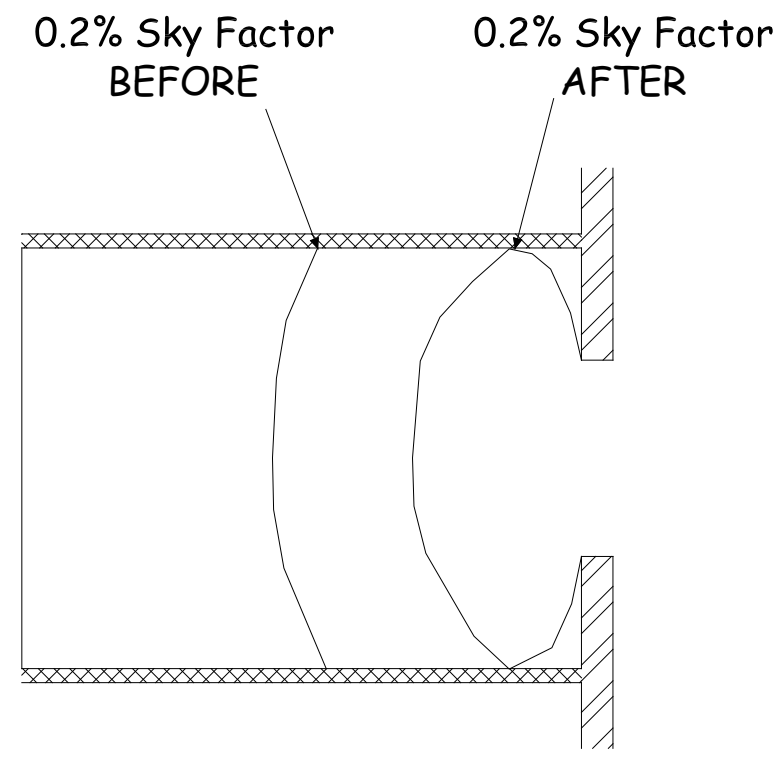

Figure 2: Daylight Plan 


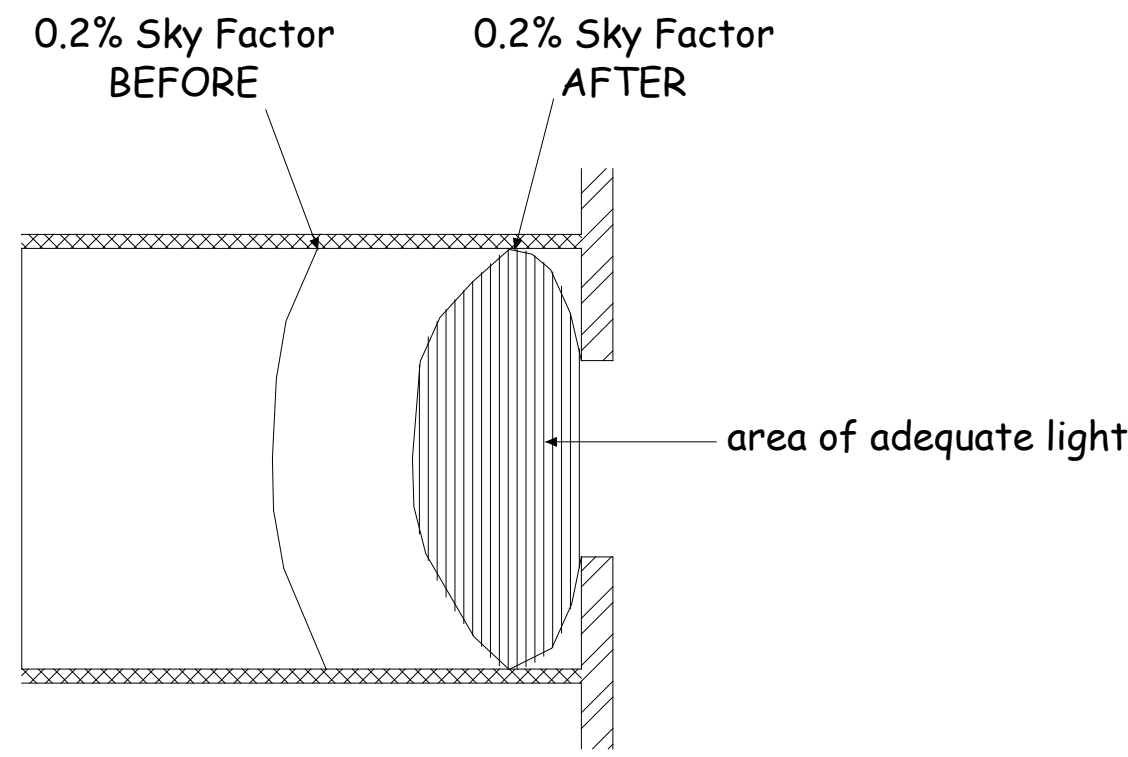

Figure 3: Infringement of right to light according to the fifty-fifty rule

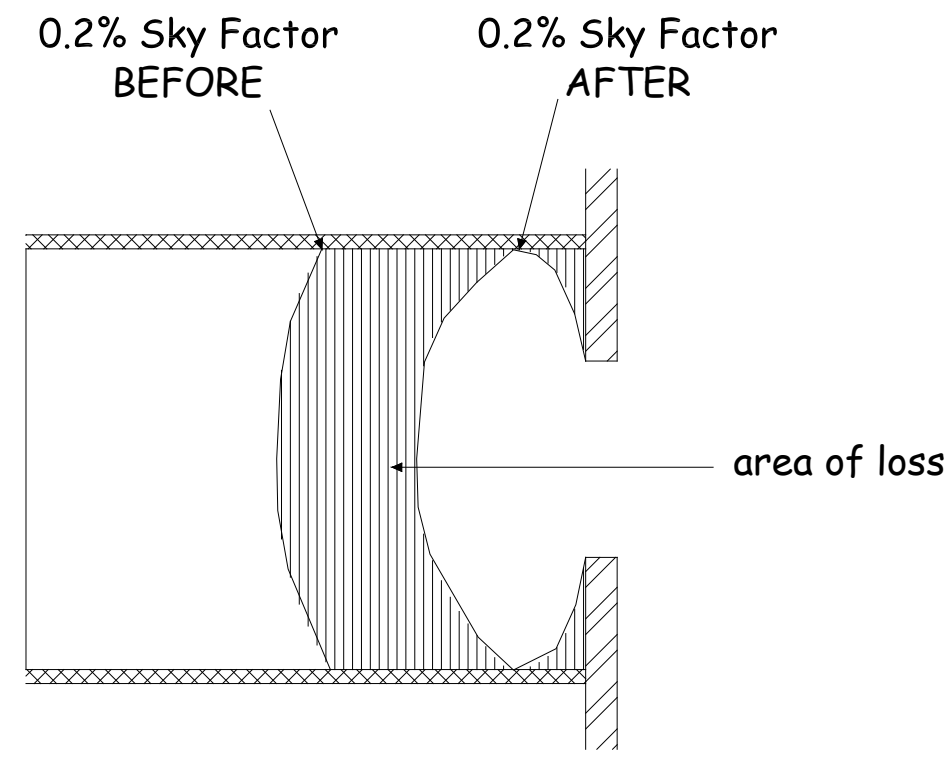

Figure 4: Valuation is based on floor area between the two contours 


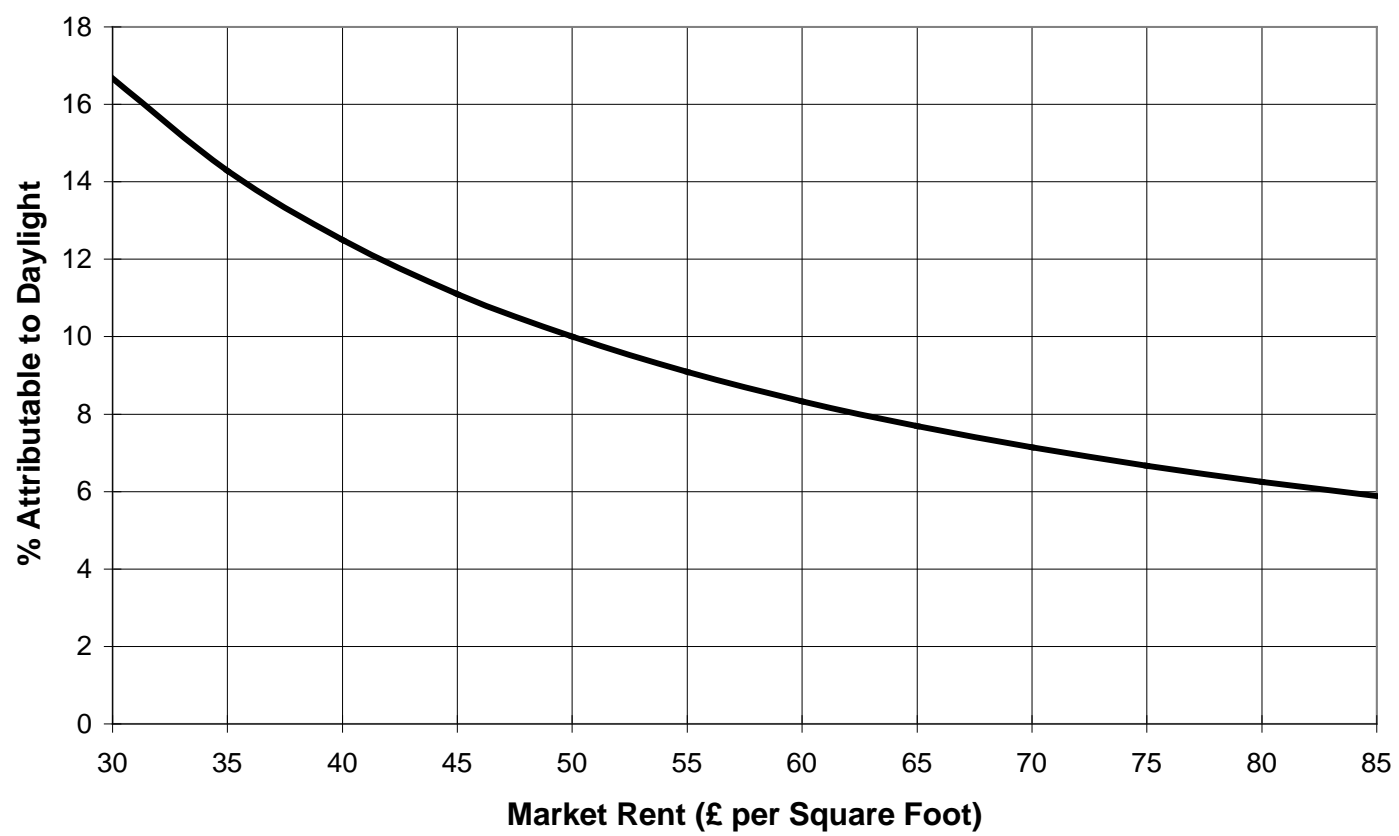

Figure 5: Market rent attributable to daylight ('high tech' London offices) 


\begin{tabular}{|c|c|c|}
\hline Category of Loss & $\begin{array}{c}\text { Percentage of room in excess } \\
\text { of } \mathbf{0 . 2 \%} \text { sky factor at point } \\
\text { where loss occurs }\end{array}$ & $\begin{array}{c}\text { Standard Floor Area } \\
\text { Weighting }\end{array}$ \\
\hline Front Zone Loss & $0 \%-25 \%$ & $150 \%$ \\
\hline First Zone Loss & $25 \%-50 \%$ & $100 \%$ \\
\hline Second Zone Loss & $50 \%-75 \%$ & $50 \%$ \\
\hline Makeweight Loss & $75 \%-100 \%$ & $25 \%$ \\
\hline
\end{tabular}

Table I: Standard Floor Area Weightings

\begin{tabular}{|l|l|l|l|l|}
\hline Owner & YP & Share of YP & $\begin{array}{l}\text { Percentage } \\
\text { Share }\end{array}$ & $\begin{array}{l}\text { Share of } \\
\text { Book Value }\end{array}$ \\
\hline $\begin{array}{l}\text { Freeholder } \\
\text { (perpetuity) }\end{array}$ & 16.6667 & $16.6667-7.3601=9.3066$ & $55.8 \%$ & $£ 14,275.31$ \\
\hline $\begin{array}{l}\text { Head- } \\
\text { Leaseholder } \\
\text { (10 years) }\end{array}$ & 7.3601 & $7.3601-4.2124=3.1477$ & $18.9 \%$ & $£ 4,835.19$ \\
\hline $\begin{array}{l}\text { Sub- } \\
\text { Leaseholder } \\
\text { (5 years) }\end{array}$ & 4.2124 & 4.2124 & $25.3 \%$ & $£ 6,472.50$ \\
\hline TOTAL & & 16.6667 & $100 \%$ & $£ 25,583$ \\
\hline
\end{tabular}

Table II: Apportionment of Book Value (Example) 


\section{References}

Anstey, J. (1981) The Valuation of Rights to Light (Property Valuation Handbook Section B4) College of Estate Management.

Anstey, J. (1988) Rights of light and how to deal with them (2 ${ }^{\text {nd }}$ edition) RICS Books.

Anstey, J. (1995) 'The Valuation of Rights to Light' Structural Survey, Vol. 13, No. 3, pp. 36 - 37.

British Standards Institution (1992) Lighting for Buildings - Part 2: Code of Practice for Daylighting (BS 8206-21992), BSI, p. 2.

Commission Internationale de L'Eclairage (1932) Recueil des Travaux et Compte Rendu des Seances, Huitieme Session, Cambridge, September 1931, Cambridge University Press, pp. 212 - 213.

Defoe, P. (1997) 'Sharing the Right to Light', CSM, September, pp. 38 - 39.

Ellis, P. (1989) Rights to Light, Estates Gazette.

Gaunt, J., \& Morgan, P. (1997) Gale on Easements, Sixteenth Edition, Sweet \& Maxwell.

Jolowicz, J. A. (1975) 'Damages in Equity - A Study of Lord Cairns' Act', Cambridge Law Journal, Vol. 34, No. 2, pp. 224 - 252.

Lawson, D. (1996) 'Light Relief’, Property Week, 11 April, pp. 28 - 29.

Pitts, M. (2000) 'The Grumble Point: Is it Still Worth the Candle?', Structural Survey, Vol. 18, No. 5, pp. 255 - 258.

Street, T. A. (1906) The Foundations of Legal Liability, Edward Thompson Company, Vol. 1.

Waldram, P. J. (1909) 'The Measurement of Illumination; Daylight \& Artificial: With Special Reference to Ancient Light Disputes', The Journal of the Society of Architects, Vol. 3, pp. 131-140.

Waldram, P. J. \& Waldram, J. M. (1923) 'Window Design and the Measurement and Predetermination of Daylight Illumination', The Illuminating Engineer, Vol. XVI, April - May, pp. 90 - 122.

Waldram, P. J. (1928) 'Daylight and Public Health', Proceedings of the Commission Internationale de L'Eclairage, Septieme Session, Saranac Inn, New York, September 1928, Chemical Publishing Co, pp. 477 - 491.

Walsh, J. W. T. (1961) The Science of Daylight, MacDonald \& Co. 


\section{Notes}

${ }^{1}$ Potts v Smith (1868) LR 6 Eq 311.

${ }^{2}$ Prescription Act 1832, s. 3.

${ }^{3}$ Colls v Home and Colonial Stores Ltd [1904] AC 179.

${ }^{4}$ Lord Lindley in Colls $v$ Home and Colonial Stores Ltd, ibid.

${ }^{5}$ Buckley LJ in Allen v Greenwood [1979] 1 All ER 819.

${ }^{6}$ Charles Semon \& Co v Bradford Corporation [1922] Ch 602.

${ }^{7}$ Cory v City of London Real Property Co Ltd (1954) 163 EG 514.

${ }^{8}$ Charles Semon \& Co v Bradford Corporation, op cit, p.749.

${ }^{9}$ Note however that this is only a guide and the courts have been unwilling to accept this as a rule of law. See, for example, Ough v King [1967] 3 All ER 859.

${ }^{10}$ Re London Tilbury and Southend Railway Company and Gowers Walk Trustees [1889] 24 QBD 326.

${ }^{11}$ The relevant legal principles for determining whether an injunction or damages are the appropriate remedy were laid down by Smith L. J. in Shelfer $v$ City of London Electric Lighting Company [1895] 1 Ch 287, at pp. 322 - 323.

${ }^{12}$ Supreme Court Act 1981, s. 50.

${ }^{13}$ Carr-Saunders v Dick McNeil Associates Limited [1986] 2 All ER 888, at p. 896. 